\title{
Optimizing Total Phenolic and Oleuropein of Chinese Olive (Olea europaea) Leaves for Enhancement of the Phenols Content and Antioxidant Activity
}

\author{
Bixia Wang ${ }^{1,2}$, Shian Shen ${ }^{2}$, Jipeng $Q u^{1,3}$, Zhou $\mathrm{Xu}^{3}$, Shiling Feng ${ }^{1}$, Tao Chen ${ }^{1}$ and Chunbang Ding ${ }^{1, *}$ \\ 1 College of Life Sciences, Sichuan Agricultural University, Yaan 625014, China; wangbixia@cwnu.edu.cn (B.W.); \\ xcc01500015@xcc.edu.cn (J.Q.); fengshilin@outlook.com (S.F.); chentao293@sicau.edu.cn (T.C.) \\ 2 College of Environmental Science and Engineering, China West Normal University, Nanchong 637009, China; \\ shenshianfm@gmail.com \\ 3 College of Agricultural Science, Xichang University, Xichang 615000, China; xzhbiol@gmail.com \\ * Correspondence: dcb@sicau.edu.cn; Tel.: +86-083-562-5014
}

check for

updates

Citation: Wang, B.; Shen, S.; Qu, J.; Xu, Z.; Feng, S.; Chen, T.; Ding, C. Optimizing Total Phenolic and

Oleuropein of Chinese Olive (Olea europaea) Leaves for Enhancement of the Phenols Content and Antioxidant Activity. Agronomy 2021, 11, 686. https://doi.org/10.3390/ agronomy11040686

Academic Editor: Salvatore Camposeo

Received: 11 March 2021

Accepted: 31 March 2021

Published: 4 April 2021

Publisher's Note: MDPI stays neutral with regard to jurisdictional claims in published maps and institutional affiliations.

Copyright: (C) 2021 by the authors Licensee MDPI, Basel, Switzerland. This article is an open access article distributed under the terms and conditions of the Creative Commons Attribution (CC BY) license (https:/ / creativecommons.org/licenses/by/ $4.0 /)$.

\begin{abstract}
China, as a contrary climate to the Mediterranean-climate region, is massive in planting olive (Olea europaea) cultivation as an important oil crop. Nonetheless, Chinese olive leaves have received little attention and there is little information about the phenols content. Therefore, in this study, a multiple-response optimization was performed to maximize the total phenolic and oleuropein content (TPC and OEC) by ultrasound-assisted extraction, and the aged and young leaves prepared from six Chinese cultivars from January to December were investigated concerning seven main phenolic composition. Under optimal conditions (power $260 \mathrm{~W}$, time $10 \mathrm{~min}$, liquid-solid ratio $30 \mathrm{~mL} / \mathrm{g}$, and 50\% ethanol), the highest TPC (197.32 mg/g DM) and OEC (74.68 mg/g DM) were obtained. Findings revealed that the optimal olive leaves for phenolic compounds were the young leaves in spring and winter, being oleuropein and luteolin-4'-O-glucoside present in higher level, and the "Koroneiki" and "Jiufeng" cultivars were relatively stable. Furthermore, antioxidant potential of the phenol extract and oleuropein was also evaluated based on the reducing power and scavenging effect on 1,1-diphenyl-2-picrylhydrazyl (DPPH)and superoxide radical assays, and a higher antioxidant effect of oleuropein was observed compared to the phenol extract. In addition, oleuropein showed anticancer activity against HeLa cells, with a minimum inhibitory concentration $\left(E_{50}\right)$ value of $0.19 \mathrm{mg} / \mathrm{mL}$ at $48 \mathrm{~h}$. These findings revealed an attractive source of biological substances for further development and utilization of Chinese olive leaves.
\end{abstract}

Keywords: olive leaves; ultrasound-assisted extraction; phenolic compounds; oleuropein; antioxidant activity

\section{Introduction}

Olive trees (Olea europaea L.), native to the Mediterranean region, were introduced into China in 1964. The cultivation area of olive in China was about 39.6 million ha in 2018 , yielding $54,000 \mathrm{t}$ of olive oil, with the cultivation area being extensively distributed in southwest provinces such as Gansu, Sichuan, and Yunnan [1]. With the industrial boom of Chinese olive, a large number of by-products have been generated yearly during cultivation and processing, yet most have no practical applications. Olive leaves, as one of these residues, are the main by-products in olive industries, representing $10 \%$ of olive fruit [2]. In China, more than 600,000 tons of olive leaves are heaped annually and are usually burned or directly scattered on fields, potentially destroying the ecological environment, creating pollution, and wasting natural plant resources [3].

Olive leaves, as traditional herbal teas used in Mediterranean folk medicine, are a rich natural source of phenolic compounds including oleuropein, rutin, luteolin-7-O-glucoside, apigenin-7-O-glucoside, and luteolin, the main component of which is oleuropein (OE), 
an intense antioxidant endowed with anti-cancer properties [4,5]. Hamd et al. have evaluated the toxicity of oleuropein and found non-toxic in several animal species [6], but on oleuropein-treated tumors, in addition to being great promise as a potential chemotherapeutic agent for the treatment of HeLa cells, it can obviously inhibit the growth of neuroblastoma, human breast cancer cells MCF-7, and human lung carcinoma A549 cells [7,8]. Olive leaf extracts have long been known for their therapeutic and medicinal properties, namely antioxidative, antimicrobial, antiproliferative, and antihypertensive activities, mainly as a result of their polyphenols $[9,10]$. There is a growing interest in utilizing phenol extract (PE) of olive leaves in various industrial applications such as food additives and nutraceuticals [11].

However, the phenolic compounds of olive leaves essentially vary by cultivar, leaf age, sampling time, climatic condition, and geographical origin $[5,12,13]$. China has a contrary climate with a Mediterranean-climate region, and Xichang city in Sichuan province is a leading producer of olives, receiving $2431.4 \mathrm{~h}$ annual average sunshine and $17.5{ }^{\circ} \mathrm{C}$ total accumulative temperature [14]. Under the unique climate conditions in China, significant differences have been found in the biochemical or genetic characteristics of olive fruit [15-17]. Although olives have been developed for 60 years in China, the existing research on olives is still mainly concentrated in the Mediterranean, while very few studies have focused on the qualification and quantification of phenols from Chinese olives, particularly olive leaves.

The development of cost-effective and sustainable extraction strategies to obtain highyield phenolic compounds is crucial for the valorization of Chinese olive leaves. Therefore, several extraction methods have been employed for detecting the phenolic compositions of olive leaves $[5,18]$. Compared to other novel extraction techniques, ultrasound-assisted extraction (UAE) of polyphenols from olive leaves is simple, rapid, and inexpensive [4]. Optimization of the extraction conditions is necessary to obtain the anti-oxidative PE, as many factors such as power, temperature, time, or solvent can influence the UAE [18]. In terms of total phenolicor oleuropein contents (TPC or OEC) in olive leaves, studies have thoroughly explored using response surface methodology (RSM), and it has been reported that artificial neural networks exhibit better prediction performance compared to RSM, though the TPC $(2.480 \pm 0.060 \mathrm{ppm})$ and OEC $(0.060 \pm 0.012 \mathrm{ppm})$ were negligible [19]. Thus far, even in more recent reviews, there is still a lack of information on the optimization of total phenolic (TP) and OE from Chinese olive leaves under the same extraction conditions.

The objective of this study was to optimize the extraction parameters for TPC and OEC of olive leaves and determine the levels of seven phenolic compounds in aged and young leaves from six Chinese olive cultivars in different seasons. In addition, the antioxidant activities of different concentrations of TP and OE were assayed in vitro by assessing the scavenging capability of DPPH radicals, superoxide anions and the reducing power, as well as the anticancer activity against HeLa cells.

\section{Materials and Methods}

\subsection{Materials and Chemicals}

\subsubsection{Plant Materials}

Six main popularized varieties ("Salonenque", "Koroneiki", “Jufeng", "Arbeqoina", "Arbosana", and "Frantoio") at Xichang, grown in the same orchard, were selected. The aged and young leaves were collected on the 20th of each month from February to December in 2019 and used for the quantitative determination of phenolic compounds, and the young leaves of the "Picual" cultivar in February were used for extraction optimization. The fresh sample was dried in a drying oven at $45^{\circ} \mathrm{C}$ until a constant weight, ground using a high-speed mill (FW177, Taisite Instrument, Tianjin, China), and then stored at $-20^{\circ} \mathrm{C}$. 


\subsubsection{Chemicals and Reagents}

HPLC-grade oleuropein, apigenin-7-O- $\beta$-D-glucosidase, luteolin- $4^{\prime}$-O-glucoside, quercetin, luteolin, apigenin, rutin, and acetonitrile were purchased from Must Biotechnology (Chengdu, China) and Acros Organics (Geel, Belgium). Dimethyl sulfoxide (DMSO), CCK-8, fetal bovine serum (FBS), penicillin, and streptomycin were purchased from Beijing Solarbio Science-technology Co., Ltd. (Beijing, China). Nicotinamide adenine dinucleotide (NADH), phenazine methosulfate (PMS), 1,1-diphenyl-2-picrylhydrazyl (DPPH), and nitroblue tetrazolium (NBT) with a purity of $98 \%$ were obtained from Sigma Chemical Co., Ltd. (St. Louis, MO, USA). All chemicals used were of analytical grade, and the water was of Milli-quality (Bedford, MA, USA).

\subsection{UAE of Phenolic Compounds}

Olive leaf powder $(1 \mathrm{~g})$ was mixed with different ethanol concentrations (50-90\%) using different liquid-solid ratios $(10-50 \mathrm{~mL} / \mathrm{g})$. These samples were extracted in an ultrasonic bath (Jiangsu, China) at various ultrasound powers (150-270 W) for varying extraction times (10-50 $\mathrm{min})$. Based on the results of the preliminary experiments, the yield of TP and OE was stable at below $60^{\circ} \mathrm{C}$, and the changes was not obvious, thus the extraction temperature was fixed at $60^{\circ} \mathrm{C}$. All extracts were centrifuged at $5000 \mathrm{rpm}$ for $10 \mathrm{~min}$ to collect the supernatant and filtered through a nylon membrane filter with $0.45-\mu \mathrm{m}$ before high-performance liquid chromatography (HPLC) analysis. Each extraction was triplicated, and all analyses were performed with three replications.

\subsection{Optimization of Total Phenolic and Oleuropein}

Response surface methodology (RSM) using Box-Behnken design (BBD) was employed to predict the influence of four independent variables on the responses (TPC and $\mathrm{OEC})$. The main factors affecting extraction efficiency, including the liquid-solid ration $\left(\mathrm{X}_{1}\right.$, $\mathrm{mL} / \mathrm{g})$, ultrasound power $\left(\mathrm{X}_{2}, \mathrm{~W}\right)$, extraction time $\left(\mathrm{X}_{3}, \mathrm{~min}\right)$, and ethanol concentration $\left(\mathrm{X}_{4}, \%\right)$, were chosen as independent factors. The coding of the four variables and their actual levels are given in Table 1, and the complete design consisted of 29 randomized runs with five replicates at the central point. The experimental and predicted values of TPC and OEC were also compared to evaluate the model validity. Runs were implemented in triplicate to certify the results. The mathematical model describing the yield of TP and OE as a function of the coded independent variable in the selected ranges was given by the following Equation (1):

$$
\mathrm{Y}=\mathrm{A}_{0}+\sum_{\mathrm{i}=1}^{4} \mathrm{~A}_{\mathrm{i}} \mathrm{x}_{\mathrm{i}}+\sum_{\mathrm{i}=1}^{4} \mathrm{~A}_{\mathrm{ii}} \mathrm{x}_{\mathrm{i}}^{2}+\sum_{\mathrm{i}<\mathrm{j}=2}^{4} \mathrm{~A}_{\mathrm{ij}} \mathrm{x}_{\mathrm{i}} \mathrm{y}_{\mathrm{j}}
$$

where $y$ is the response function (TPC and OEC); $A_{0}$ is a constant; $A_{i}, A_{i i}$, and $A_{i j}$ are coefficients of the linear, quadratic, and interaction coefficients, respectively; $x_{i}$ and $x_{j}$ are the independent factors.

Table 1. Box-Behnken design (BBD) design with the experiment variables and experimental data for the responses.

\begin{tabular}{|c|c|c|c|c|c|c|}
\hline \multirow[b]{2}{*}{ Run } & \multicolumn{4}{|c|}{ Extraction Variables } & \multirow{2}{*}{$\begin{array}{l}\text { TPC } \\
\text { (mg/g DM) }\end{array}$} & \multirow{2}{*}{$\begin{array}{l}\text { OEC } \\
(\mathrm{mg} / \mathrm{g} \mathrm{DM})\end{array}$} \\
\hline & $\begin{array}{l}X_{1}(\mathrm{~mL} / \mathrm{g}) \\
\text { Liquid-Solid Ratio }\end{array}$ & $\begin{array}{l}X_{2}(W) \\
\text { Power }\end{array}$ & $\begin{array}{l}X_{3}(\min ) \\
\text { Tim }\end{array}$ & $\begin{array}{l}\mathrm{X}_{4}(\%) \\
\text { Concentration }\end{array}$ & & \\
\hline 1 & $0(20)$ & $0(240)$ & $0(20)$ & $0(60)$ & 188.79 & 72.72 \\
\hline 2 & $-1(10)$ & $1(270)$ & $0(20)$ & $0(60)$ & 183.00 & 71.57 \\
\hline 3 & $-1(10)$ & $0(240)$ & $1(30)$ & $0(60)$ & 184.48 & 71.93 \\
\hline 4 & $0(20)$ & $-1(210)$ & $0(20)$ & $1(70)$ & 155.48 & 67.56 \\
\hline 5 & $1(30)$ & $0(240)$ & $0(20)$ & $-1(50)$ & 166.62 & 69.88 \\
\hline 6 & $0(20)$ & $0(240)$ & $0(20)$ & $0(60)$ & 196.31 & 72.61 \\
\hline 7 & $0(20)$ & $1(270)$ & $-1(10)$ & $0(60)$ & 187.68 & 72.31 \\
\hline 8 & $-1(10)$ & $-1(210)$ & $0(20)$ & $0(60)$ & 172.54 & 72.84 \\
\hline
\end{tabular}


Table 1. Cont.

\begin{tabular}{|c|c|c|c|c|c|c|}
\hline \multirow[b]{2}{*}{ Run } & \multicolumn{4}{|c|}{ Extraction Variables } & \multirow{2}{*}{$\begin{array}{l}\text { TPC } \\
\text { (mg/g DM) }\end{array}$} & \multirow{2}{*}{$\begin{array}{l}\text { OEC } \\
(\mathrm{mg} / \mathrm{g} \text { DM) }\end{array}$} \\
\hline & $\begin{array}{l}\mathrm{X}_{1}(\mathrm{~mL} / \mathrm{g}) \\
\text { Liquid-Solid Ratio }\end{array}$ & $\begin{array}{l}X_{2}(W) \\
\text { Power }\end{array}$ & $\begin{array}{l}X_{3}(\min ) \\
\text { Tim }\end{array}$ & $\begin{array}{l}X_{4}(\%) \\
\text { Concentration }\end{array}$ & & \\
\hline 9 & $1(30)$ & $0(240)$ & $1(30)$ & $0(60)$ & 149.77 & 66.00 \\
\hline 10 & $0(20)$ & $-1(210)$ & $-1(10)$ & $0(60)$ & 172.25 & 71.15 \\
\hline 11 & $0(20)$ & $0(240)$ & $0(20)$ & $0(60)$ & 190.35 & 73.14 \\
\hline 12 & $0(20)$ & $-1(210)$ & $1(30)$ & $0(60)$ & 181.54 & 71.48 \\
\hline 13 & $0(20)$ & $0(240)$ & $-1(10)$ & $-1(50)$ & 189.03 & 70.44 \\
\hline 14 & $-1(10)$ & $0(240)$ & $0(20)$ & $1(70)$ & 164.92 & 68.89 \\
\hline 15 & $0(20)$ & $-1(210)$ & $0(20)$ & $-1(50)$ & 166.55 & 68.49 \\
\hline 16 & $0(20)$ & $0(240)$ & $0(20)$ & $0(60)$ & 197.00 & 73.00 \\
\hline 17 & $0(20)$ & $0(240)$ & $0(20)$ & $0(60)$ & 196.83 & 72.82 \\
\hline 18 & $-1(10)$ & $0(240)$ & $0(20)$ & $-1(50)$ & 162.68 & 68.08 \\
\hline 19 & $-1(10)$ & $0(240)$ & $-1(10)$ & $0(60)$ & 175.40 & 70.66 \\
\hline 20 & $1(30)$ & $1(270)$ & $0(20)$ & $0(60)$ & 156.54 & 70.52 \\
\hline 21 & $0(20)$ & $1(270)$ & $1(30)$ & $0(60)$ & 153.09 & 66.83 \\
\hline 22 & $0(20)$ & $1(270)$ & $0(20)$ & $-1(50)$ & 168.37 & 69.00 \\
\hline 23 & $1(30)$ & $0(240)$ & $-1(10)$ & $0(60)$ & 186.93 & 71.78 \\
\hline 24 & $1(30)$ & $-1(210)$ & $0(20)$ & $0(60)$ & 169.31 & 69.89 \\
\hline 25 & $0(20)$ & $0(240)$ & $1(30)$ & $-1(50)$ & 139.56 & 65.49 \\
\hline 26 & $0(20)$ & $1(270)$ & $0(20)$ & $1(70)$ & 129.00 & 63.91 \\
\hline 27 & $0(20)$ & $0(240)$ & $1(30)$ & $1(70)$ & 140.46 & 65.12 \\
\hline 28 & $1(30)$ & $0(240)$ & $0(20)$ & $1(70)$ & 110.79 & 61.52 \\
\hline 29 & $0(20)$ & $0(240)$ & $-1(10)$ & $1(70)$ & 132.55 & 64.60 \\
\hline Predicted & 30 & 260.57 & 10.00 & 53.09 & 197.12 & 74.35 \\
\hline Experimental & 130 & 260.00 & 10.00 & 50.00 & 197.32 & 74.68 \\
\hline
\end{tabular}

\subsection{Determination of TPC}

The TPC of the olive leaf extracts was determined using the Folin-Ciocalteu method [20]. The absorbance was measured at $760 \mathrm{~nm}$ with a microplate reader (Spectramax M2, USA). The TPC results were expressed as milligrams of gallic acid equivalent per gram dry matter $(\mathrm{mg} / \mathrm{g} \mathrm{DM})$. All experiments were repeated at least three times.

\subsection{Quantification of Phenolic Compounds Using HPLC}

The compound analysis was performed using an HPLC system (Agilent 1260, Agilent Technologies, California, CA, USA). The gradient elution, at a flow rate of $0.8 \mathrm{~mL} / \mathrm{min}$, was achieved using the method previously established by Wang et al. [21]. The column temperature was maintained at $30^{\circ} \mathrm{C}$, and the injection volume was $10 \mu \mathrm{L}$. The HPLC system with a UV-VIS DAD detector at $350 \mathrm{~nm}$ was coupled to a Zorbax Eclipse Plus- $\mathrm{C}_{18}$ column $(5.0 \mu \mathrm{m}, 150 \times 4.6 \mathrm{~mm})$, and the mobile phase consisted of a mixture of water $(0.2 \%$ aqueous phosphoric acid, solvent $\mathrm{A}$ ) and acetonitrile (solvent $\mathrm{B}$ ): $0-5 \mathrm{~min}, 84 \% \mathrm{~A} ; 5-20 \mathrm{~min}$, $84-70 \%$ A; $20-25 \mathrm{~min}, 70-60 \%$ A; $25-30 \mathrm{~min}, 60-84 \%$ A; $30-35 \mathrm{~min}, 84 \%$ A. The amounts of phenolic compounds were calculated using the calibration curve $(\mathrm{C})$, and the equation was as follows: content of phenolic compounds $(\mathrm{mg} / \mathrm{g})=((\mathrm{C} \times \mathrm{V}) / \mathrm{W}) / 1000$, where $\mathrm{V}$ is the volume of the extract $(\mathrm{mL})$, and $\mathrm{W}$ is the dried weight of sample (g). All compound contents were reported as mg of compound/g dry matter (DM).

Oleuropein in the extracted solutions was analyzed as follows: the determined wavelength, $254 \mathrm{~nm}$; column temperature, $30^{\circ} \mathrm{C}$; flow rate, $10 \mu \mathrm{L}$; and water $(75 \%)$ and acetonitrile $(25 \%)$ were used as mobile phase $\mathrm{A}$ and mobile phase $\mathrm{B}$ at $0.8 \mathrm{~mL} / \mathrm{min}$, respectively. The data were expressed as means of the mg oleuropein per $\mathrm{g}$ dry matter.

\subsection{Evaluation of Antioxidant Activities}

The DPPH and superoxide radical assays were performed as previously reported with modifications [22]. For the DPPH assay, the reaction mixture contained $135 \mu \mathrm{L}$ of the DPPH 
solution $(0.4 \mathrm{mM})$ and the phenol extracts and oleuropein $(0.2-1.2 \mathrm{mg} / \mathrm{mL})$ dissolved in methanol. The mixture was shaken vigorously and incubated at $37^{\circ} \mathrm{C}$ in the dark for $10 \mathrm{~min}$. The absorbance at $517 \mathrm{~nm}$ (Spectramax M2) was measured. For the superoxide radical scavenging assay, different concentrations of phenol extracts and oleuropein were mixed with $0.2 \mathrm{~mL}$ NBT $(0.08 \mathrm{mM}), 0.4 \mathrm{~mL} \mathrm{NADH}(0.25 \mathrm{mM})$, and $0.2 \mathrm{~mL}$ PMS $(0.06 \mathrm{mM})$ at $25^{\circ} \mathrm{C}$ for $25 \mathrm{~min}$, and the absorbance was recorded at $560 \mathrm{~nm}$. The DPPH and superoxide radical scavenging activity (\%) were calculated from the following equation: radical scavenging activity $\left.(\%)=\left(\mathrm{A}_{\text {control }}-\mathrm{A}_{\text {sample }}\right) / \mathrm{A}_{\text {control }}\right) \times 100$. The $\mathrm{EC}_{50}$ values $(\mathrm{mg} / \mathrm{mL})$, defined as the concentration of the sample that gave $50 \%$ maximal response, were calculated from the plot of \% inhibition against concentration. Ascorbic acid (Vc) served as the positive control, and all the analyses were carried out in triplicate.

The reducing power assay was performed as previously reported [23]. Briefly, $0.2 \mathrm{~mL}$ of the sample (phenol extract and oleuropein) was mixed with $0.5 \mathrm{~mL}$ of phosphate buffer $(0.2 \mathrm{M}, \mathrm{pH}$ 6.6) and $0.5 \mathrm{~mL}$ of $1 \%$ potassium ferricyanide. The mixture was incubated at $50{ }^{\circ} \mathrm{C}$ for $20 \mathrm{~min}$. Then, $0.5 \mathrm{~mL}$ of $10 \%$ trichloroacetic acid was added after cooling, and the mixture was centrifuged at $3000 \mathrm{rpm}$ for $10 \mathrm{~min}$. Subsequently, $0.5 \mathrm{~mL}$ supernatant was diluted in $0.5 \mathrm{~mL}$ of distilled water and reacted with $0.1 \mathrm{~mL} 0.1 \%$ ferric chloride. The effective concentration ( $\mathrm{EC}_{50}, \mathrm{mg} / \mathrm{mL}$ ) giving 0.5 of absorbance (the $50 \%$ maximal response) was calculated from the plot of absorbance at $700 \mathrm{~nm}$ against the extract concentration. All tests were carried out in triplicate.

\subsection{Evaluation of Anticancer Activity}

Human tumor cervical HeLa cells (Sichuan University, Chengdu, China) were cultured in Dulbecco's modified Eagle's medium (DMEM) (1\% penicillin-streptomycin solutions and $10 \%$ fetal bovine serum (FBS) in a humidified $5.0 \% \mathrm{CO}_{2}$ incubator at $37{ }^{\circ} \mathrm{C}$. The cells were treated with different oleuropein concentrations $(0.4-2.0 \mathrm{mg} / \mathrm{mL})$ and incubated for 12,24 , and $48 \mathrm{~h}$ in $100 \mu \mathrm{L}$ of fresh growth medium. Then, $10 \mu \mathrm{L} \mathrm{CCK}-8$ was added into the cell wells for $1 \mathrm{~h}$. The absorbance was measured at $450 \mathrm{~nm}$, and the experiment was carried out in triplicate for each sample. Cell viability was measured as follows: Cell viability (\%) $=\left(\left(\mathrm{A}_{\text {sample }}-\mathrm{A}_{\text {control }}\right) /\left(\mathrm{A}_{\text {cell }}-\mathrm{A}_{\text {control }}\right)\right) \times 100$, where $\mathrm{A}_{\text {sample }}$ is the absorbance of a well with cells, the CCK-8 solution, and sample solution; $\mathrm{A}_{\text {control }}$ is the absorbance of a well with the medium and the CCK-8 solution, without cells; $\mathrm{A}_{\text {cell }}$ is the absorbance of a well with cells and the CCK-8 solution, without the sample solution.

\subsection{Statistical Analysis}

All experiments were carried out in triplicate, and the data were reported as mean \pm standard deviation (SD). The experimental results of response surface design were analyzed using the Design-Expert 10 software (Trial version, State-Ease Inc., Minneapolis, MN, USA). Statistical analysis included one-way analyses of variance (ANOVA) in SPSS version 17 (SPSS Inc., Chicago, IL, USA).

\section{Results}

3.1. Extraction Optimization of TP and $O E$

3.1.1. Single-Factor Experiment

At the beginning of this study, the liquid-solid ratio, ultrasound power, extraction time, and ethanol concentration were investigated to determine the appropriate experimental ranges to be considered during the optimization process. The amount of TP and OE from the olive leaves is presented in Figure 1. Figure 1A showed a similar influence of liquidsolid ratio on the TPC and OEC, with a significant difference in the range of $10-50 \mathrm{~mL} / \mathrm{g}$. The yield increased with the increase in the liquid-solid ratio and peaked at $20 \mathrm{~mL} / \mathrm{g}$, which was probably because polyphenols, especially in the form of glycosides, have higher yields in high-solubility hydroalcoholic solutions [18]. This indicated that $20 \mathrm{~mL} / \mathrm{g}$ was the optimal liquid-solid ratio. A similar trend in TPC and OEC was observed regarding the effect of ultrasound power in Figure 1B. An increase in the TPC and OEC at a higher power 
was achieved, reaching the highest at $240 \mathrm{~W}$. When the power was higher than $240 \mathrm{~W}$, the TPC and OEC began to decline, dropping to 204.12 and $73.78 \mathrm{mg} / \mathrm{g}$ at $270 \mathrm{~W}$, and thus the maximum power was fixed at $240 \mathrm{~W}$. Extraction time was another important variable to consider. Figure $1 \mathrm{C}$ shows that the TPC and OEC at $20 \mathrm{~min}$ were significantly higher than at $10 \mathrm{~min}$, and when the time was prolonged to $30 \mathrm{~min}$, the TPC and OEC decreased from 206.37 to 200.94 and $74.40 \mathrm{mg} / \mathrm{g}$ to $73.0 \mathrm{mg} / \mathrm{g}$, respectively. Hence, $20 \mathrm{~min}$ was considered the optimal time. Simultaneously, different ethanol concentrations were also assessed at a range from 50\% to $90 \%$ (Figure 1D). The TPC and OEC at 70\% ethanol were maximized that was maybe higher concentration of aqueous ethanol improved the yield of phenolics due to its polarity; however, this trend declined when the ethanol concentration varied from $70 \%$ to $90 \%$, suggesting that the optimal ethanol concentration was $70 \%$, which was in accordance with previous results for phenolic compounds of pomegranate peel [24].

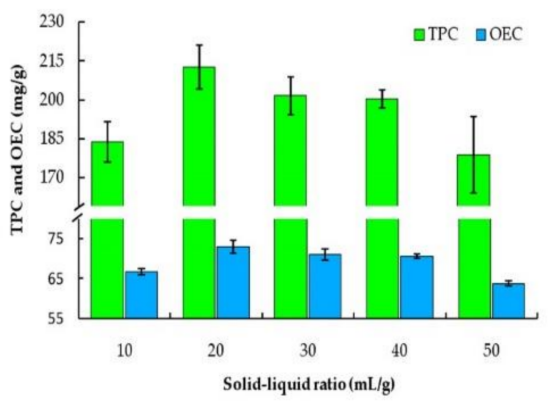

(A)

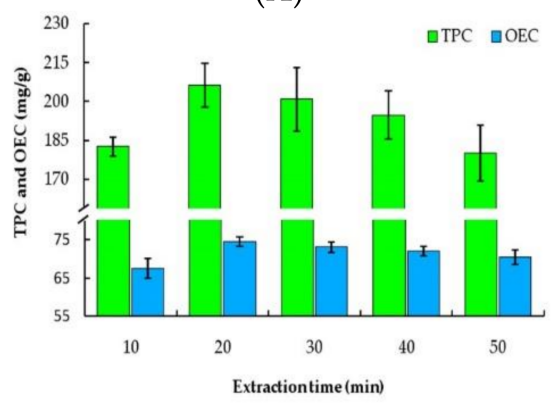

(C)

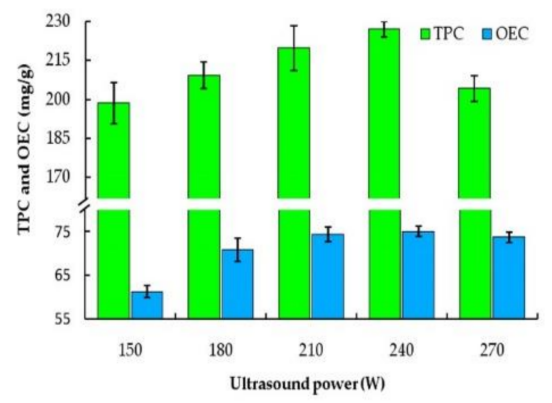

(B)

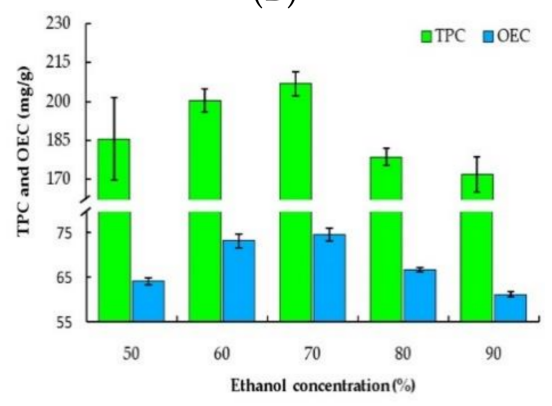

(D)

Figure 1. Single-factor effect on the total phenolic and oleuropein content (TPC and OEC): (A), solid-liquid ratio; (B), ultrasound power; (C), extraction time; (D), ethanol concentration.

\subsubsection{Extraction Model Analysis}

Based on the single-factor experiment, the phenolic extraction from olive leaves was further optimized for the maximum TPC and OEC using the RSM approach. The design variables in their coded form and the corresponding response values from the 29 treatments are displayed in Table 1. A second-order polynomial model, expressing the correlation between the extraction yield and four variables, was achieved as below in Equations (2) and (3):

$\mathrm{Y}_{\mathrm{TPC}}=193.86-8.59 \times_{1}-3.33 \mathrm{X}_{2}-7.91 \mathrm{X}_{3}-13.30 \mathrm{X}_{4}-5.81 \mathrm{X}_{1} \mathrm{X}_{2}-11.56 \mathrm{X}_{1} \mathrm{X}_{3}-4.52 \mathrm{X}_{1} \mathrm{X}_{4}-10.97 \mathrm{X}_{2} \mathrm{X}_{3}-7.07 \mathrm{X}_{2} \mathrm{X}_{4}+14.34 \mathrm{X}_{3} \mathrm{X}_{4}-11.49 \mathrm{X}_{12}-9.95 \mathrm{X}_{22}-10.27 \mathrm{X}_{32}-31.12 \mathrm{X}_{42}$

$\mathrm{Y}_{\mathrm{OEC}}=72.86-1.20 \mathrm{X}_{1}-0.61 \mathrm{X}_{2}-1.17 \mathrm{X}_{3}-1.65 \mathrm{X}_{4}+0.48 \mathrm{X}_{1} \mathrm{X}_{2}-1.76 \mathrm{X}_{1} \mathrm{X}_{3}-2.29 \mathrm{X}_{1} \mathrm{X}_{4}-1.45 \mathrm{X}_{2} \mathrm{X}_{3}-1.04 \mathrm{X}_{2} \mathrm{X}_{4}+1.37 \mathrm{X}_{3} \mathrm{X}_{4}-0.98 \mathrm{X}_{12}-0.73 \mathrm{X}_{22}-1.70 \mathrm{X}_{32}-4.80 \mathrm{X}_{42}$

The effects (linear, quadratic, and interaction) of the independent variables derived from the statistical analysis by $F$-test and ANOVA are presented in Table 2, and the statistical significance of Equations (2) and (3) was investigated for the quadratic equations of TPC and OEC. The $p$-value was employed to test the significance of each coefficient, and the higher the $F$-value, the lower the $p$-value, and the more significant the coefficient [25]. In our study, the $p$-values were less than 0.0001 , and the $F$-values of TPC and OEC were 40.56 
and 126.71, denoting that the regression models were extremely significant. Meanwhile, the lack-of-fit test of TPC (0.0951) and OEC (0.0821) was not significant, and this predicting mode could forecast the TPC and OEC according to the UAE parameters. For the fixed model, a goodness-of-fit test was used to verify the high coefficient of determination $\left(\mathrm{R}^{2}\right)$ [26]. A high degree of correlation between the predicted and experimental values was also found for TPC and OEC due to the similarity of $\mathrm{R}^{2}$ (TPC, 0.9759; OEC, 0.9922) and their $\mathrm{R}^{2}$ adj (TPC, 0.9519; OEC, 0.9843). In addition, $\mathrm{X}_{4}$ had the most important impact on TPC and OEC, followed by $X_{1}$ and $X_{3}$, and finally $X_{2}$. The interactions of $X_{1} X_{3}, X_{1} X_{4}$, $X_{2} X_{3}$, and $X_{3} X_{4}$ on the OEC were more noticeable than those of $X_{1} X_{2}$ and $X_{2} X_{4}$, and the quadratic terms $X_{12}, X_{22}, X_{32}$, and $X_{42}$ were highly significant $(p<0.0001)$. While for the OEC, all interaction and quadratic terms were significantly higher than that of the interaction of $\mathrm{X}_{1} \mathrm{X}_{2}$.

Table 2. ANOVA for response surface quadratic equations of TPC and OEC by ultrasound-assisted extraction (UAE).

\begin{tabular}{|c|c|c|c|c|c|c|c|c|c|c|}
\hline \multirow{2}{*}{ Factor } & \multicolumn{5}{|c|}{ TPC } & \multicolumn{5}{|c|}{ OEC } \\
\hline & SS & DF & MS & $F$-Value & $p$-Value & SS & DF & MS & $F$-Value & $p$-Value \\
\hline Model & 13536.65 & 14 & 966.90 & 40.56 & $<0.0001^{* * *}$ & 279.95 & 14 & 20.00 & 126.71 & $<0.0001^{* * *}$ \\
\hline $\mathrm{X}_{1}$ & 885.11 & 1 & 885.11 & 37.13 & $<0.0002 * *$ & 17.23 & 1 & 17.23 & 109.19 & $<0.0002 * *$ \\
\hline$x_{2}$ & 133.27 & 1 & 133.27 & 5.59 & 0.0330 * & 4.40 & 1 & 4.40 & 27.91 & $0.0002 * *$ \\
\hline$x_{3}$ & 751.13 & 1 & 751.13 & 31.51 & $<0.0002^{* *}$ & 16.54 & 1 & 16.54 & 104.83 & $<0.0002 * *$ \\
\hline$X_{4}$ & 2122.95 & 1 & 2122.95 & 89.06 & $<0.0002 * *$ & 32.60 & 1 & 32.60 & 206.60 & $<0.0002 * *$ \\
\hline$X_{1} X_{2}$ & 134.91 & 1 & 134.91 & 5.66 & $0.0322 *$ & 0.90 & 1 & 0.90 & 5.72 & 0.0314 * \\
\hline$x_{1} X_{3}$ & 334.53 & 1 & 534.53 & 22.42 & $0.0003 * *$ & $X_{1} X_{3}$ & 12.43 & 1 & 12.43 & 78.73 \\
\hline$X_{1} X_{4}$ & 843.03 & 1 & 843.03 & 35.37 & $<0.0002 * *$ & $\mathrm{X}_{1} \mathrm{X}_{4}$ & 21.02 & 1 & 21.02 & 133.21 \\
\hline $\mathrm{X}_{2} \mathrm{X}_{3}$ & 481.36 & 1 & 481.36 & 20.19 & $0.0005^{* *}$ & $X_{2} X_{3}$ & 8.44 & 1 & 8.44 & 33.47 \\
\hline$X_{2} X_{4}$ & 200.22 & 1 & 200.22 & 8.40 & $0.0227 *$ & $X_{2} X_{4}$ & 4.33 & 1 & 4.33 & 27.41 \\
\hline$X_{3} X_{4}$ & 823.12 & 1 & 823.12 & 34.53 & $<0.0002 * *$ & $X_{3} X_{4}$ & 7.48 & 1 & 7.48 & 47.40 \\
\hline $\mathrm{X}_{1}^{2}$ & 857.04 & 1 & 857.04 & 35.95 & $<0.0002 * *$ & $\mathrm{X}_{12}$ & 6.25 & 1 & 6.25 & 39.59 \\
\hline$x_{2}^{2}$ & 641.97 & 1 & 641.97 & 26.93 & $0.0002 * *$ & $X_{22}$ & 3.48 & 1 & 3.48 & 22.07 \\
\hline$X_{3}^{2}$ & 684.77 & 1 & 684.77 & 28.73 & $0.0002 * *$ & $X_{32}$ & 18.81 & 1 & 18.81 & 119.17 \\
\hline$X_{4}^{2}$ & 6280.22 & 1 & 6280.22 & 263.45 & $<0.0002 * *$ & $X_{42}$ & 149.70 & 1 & 149.70 & 948.56 \\
\hline $\begin{array}{c}\text { Lack of } \\
\text { Fit }\end{array}$ & 271.02 & 10 & 27.10 & 1.73 & $0.3149 \mathrm{~ns}$ & $\begin{array}{c}\text { Lack of } \\
\text { Fit }\end{array}$ & 2.03 & 10 & 0.20 & 4.46 \\
\hline Residual & 333.73 & 14 & 23.84 & & & Residual & 2.21 & 14 & 0.16 & \\
\hline $\begin{array}{l}\text { Pure } \\
\text { Error }\end{array}$ & 62.71 & 4 & 15.68 & & & $\begin{array}{l}\text { Pure } \\
\text { Error }\end{array}$ & 0.18 & 4 & 0.045 & \\
\hline Cor Total & 13870.38 & 28 & & & & Cor Total & 282.16 & 28 & & \\
\hline $\mathrm{R}^{2}$ & 0.9759 & & & & & 0.9922 & & & & \\
\hline $\mathrm{R}^{2}$ adj & 0.9519 & & & & & 0.9843 & & & & \\
\hline
\end{tabular}

*** Highly significant $(p<0.0001) ;{ }^{* *}$ more significant $(p<0.001) ;{ }^{*}$ significant $(p<0.05)$; ns, not significant $(p>0.05)$. $\left(\mathrm{X}_{1}\right)$ liquid-solid ratio $(\mathrm{mL} / \mathrm{g}) ;\left(\mathrm{X}_{2}\right)$ ultrasonic power $(\mathrm{W}) ;\left(\mathrm{X}_{3}\right)$ time $(\mathrm{min}) ;\left(\mathrm{X}_{4}\right)$ concentration $(\%)$. SS, sum squares; DF, degree of freedom; MS, mean square.

\subsubsection{Response Surface Analysis}

To illustrate the interaction effects of the independent variables on the responses ( $\mathrm{Y}_{\text {TPC }}$ and $\mathrm{Y}_{\mathrm{OEC}}$ ), a three-dimensional (3D) response surface is presented (Figures 2 and 3), in which two constants at the central level and two varying variables at the detection range are presented. As can be seen in Figure 2A, D, the interaction of $X_{1} X_{2}$ at 20 min and $70 \%$ ethanol exhibited a similar effect on the TPC and OEC. The effects of $X_{1} X_{2}$ on TPC and OEC displayed a linear increase at first but decreased after a certain value (approximately $20 \mathrm{~mL} / \mathrm{g}, 240 \mathrm{~W})$. Similar impacts of $X_{1} X_{3}$ and $X_{1} X_{4}$ on the TPC and OEC were observed in Figure $2 B, C, E, F$. The figures clearly showed the positive effects between the variables $\left(X_{1} X_{3}\right.$ and $\left.X_{1} X_{4}\right)$; indeed, the highest yields of TP and $\mathrm{OE}$ were obtained with about $20 \mathrm{~mL} / \mathrm{g}$, $20 \mathrm{~min}$, and $70 \%$ ethanol. Wang et al. found that ultrasound enabled the maximum yield of total phenols from Sparganii rhizome in $40 \mathrm{~min}$ and $19.21 \mathrm{~mL} / \mathrm{g}$ [27]. 


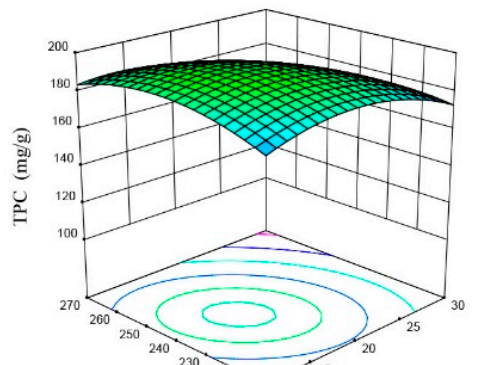

X2: Power (W) ${ }_{220}^{230} \underset{210}{ }{ }_{10} \quad \mathrm{X} 1$ : Ratio $(\mathrm{g} / \mathrm{mL})$

(A)

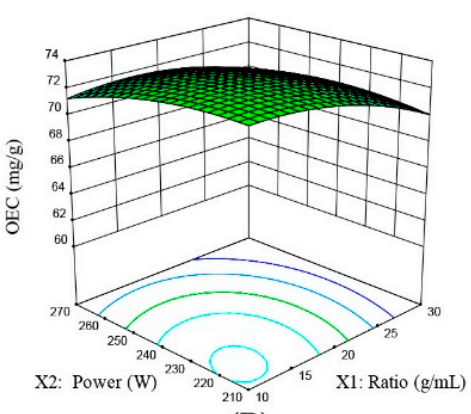

(D)

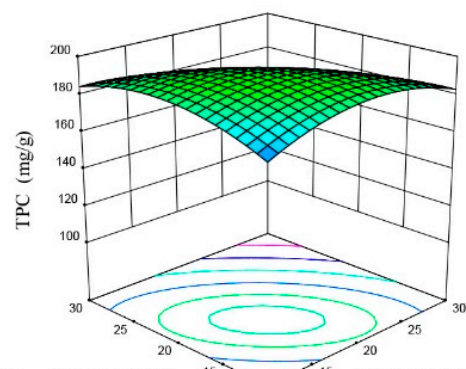

(B)

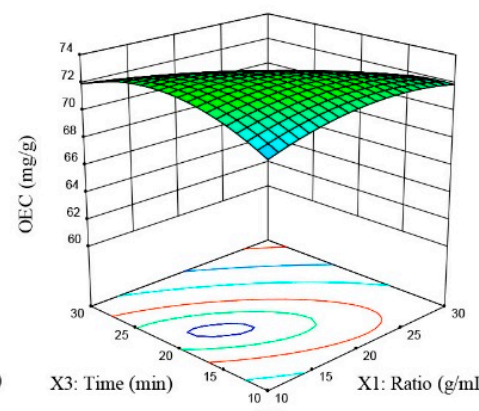

(E)

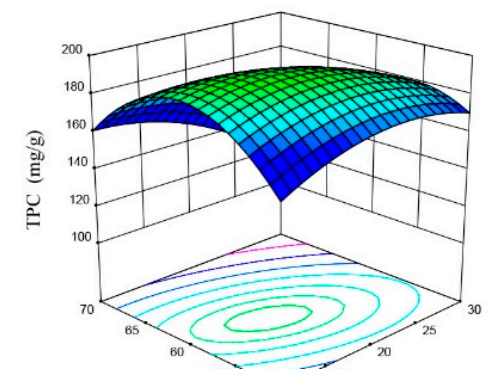

${ }^{50}$ (C)

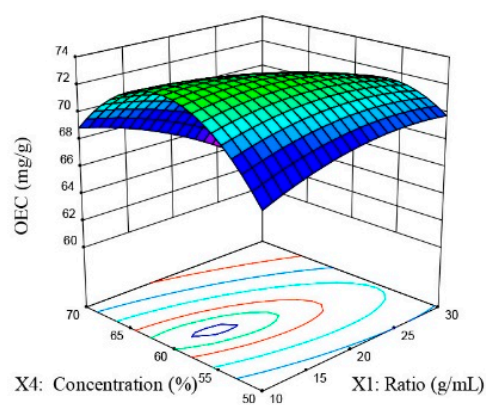

(F)

Figure 2. Response surface plot for the interactions of solid-liquid ratio, extraction time and ethanol concentration on TPC $(\mathrm{mg} / \mathrm{g} \mathrm{DM},(\mathbf{A}-\mathbf{C}))$ and OEC (mg/g DM, (D-F)) by UAE.

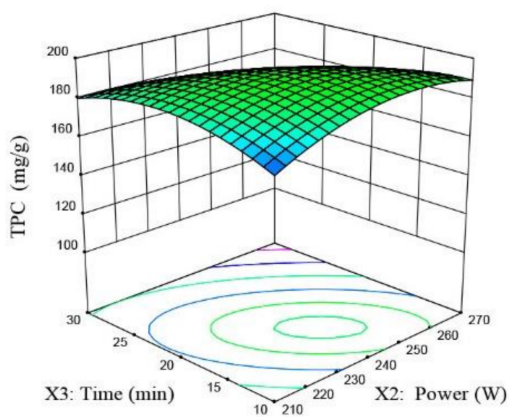

(A)

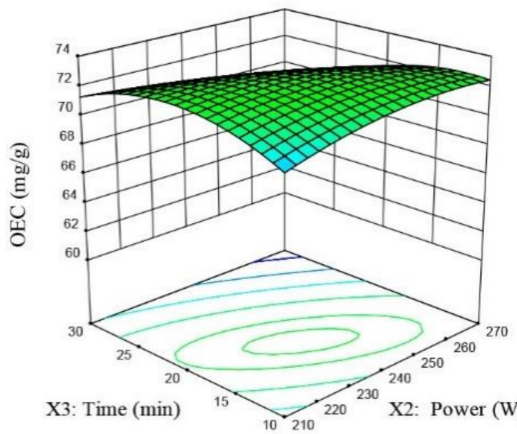

(D)

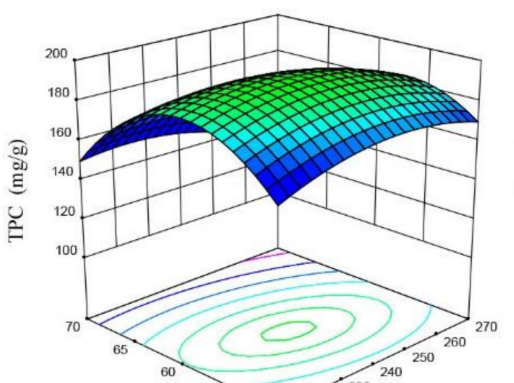

(B)

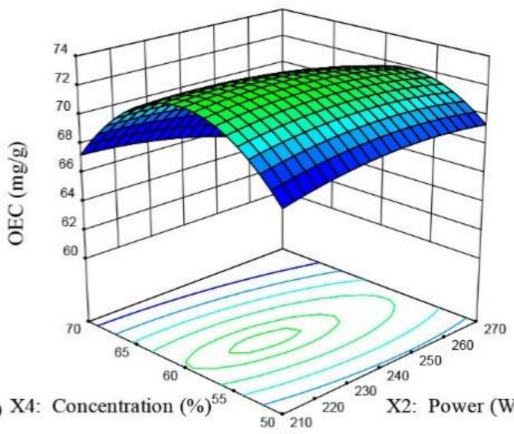

(E)

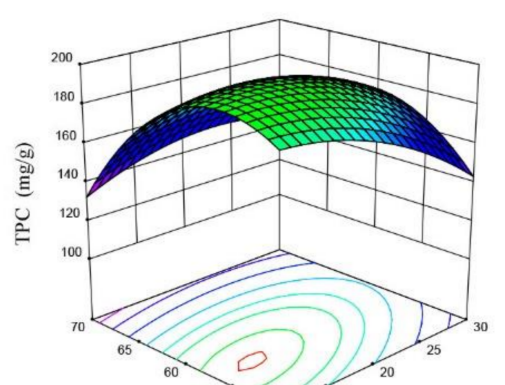

${ }_{50} 10$

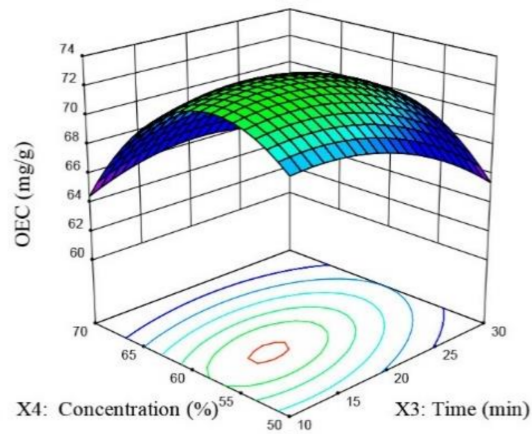

(F)

Figure 3. Response surface plot for the interactions of ultrasound power, ethanol concentration and extraction time on TPC (mg/g DM, (A-C)) and OEC (mg/g DM, (D-F)) by UAE.

In Figure $3 A, D$, the effect of $X_{2} X_{3}$ on the TPC and OEC was also investigated when $X_{1}$ and $X_{4}$ were fixed at $20 \mathrm{~mL} / \mathrm{g}$ and $60 \%$. The TPC and OEC were enhanced with the increase in power and time. The maximum values of TPC $(195.38 \mathrm{mg} / \mathrm{g})$ and OEC (73.05 mg/g) were achieved in $20 \mathrm{~min}$ and $240 \mathrm{~W}$, which may be due to the degradation and fragmentation of phenolic compounds caused by cavitation bubbles using ultrasound 
waves, thus increasing the yield [28]. In these experimental conditions, high power $\left(\mathrm{X}_{2}\right)$ and high ethanol $\left(\mathrm{X}_{4}\right)$ increased the TPC and OEC (Figure 3B,E); however, if the power $(270 \mathrm{~W})$ and concentration $(70 \%)$ were too high, an adverse effect was observed. Similarly, once the time $\left(\mathrm{X}_{3}\right)$ and ethanol $\left(\mathrm{X}_{4}\right)$ exceeded $20 \mathrm{~min}$ and $60 \%$, respectively, the TPC and OEC began to decline (Figure 3C,F). This drop may be associated with the fact that too high a concentration $(70 \%)$ and long time (30 $\mathrm{min})$ increased the impurities, thereby preventing the dissolution of phenolic compounds [4].

\subsubsection{Optimization of the Extraction Conditions}

Based on the responses $\left(\mathrm{Y}_{\mathrm{TPC}}\right.$ and $\left.\mathrm{Y}_{\mathrm{OEC}}\right)$, the optimal parameters were verified as follows: liquid-solid ratio $29.99 \mathrm{~mL} / \mathrm{mg}$, power of $260.47 \mathrm{~W}$, time of $10 \mathrm{~min}$, and ethanol of $53.27 \%$. The experimental values for TPC $(197.32 \pm 2.08 \mathrm{mg} / \mathrm{g})$ and OEC $(74.68 \pm 1.23 \mathrm{mg} / \mathrm{g})$ were very close to the predicted values $(197.12 \mathrm{mg} / \mathrm{g} ; 74.35 \mathrm{mg} / \mathrm{g})$ under actual operating conditions $(30 \mathrm{~mL} / \mathrm{g}, 240 \mathrm{~W}, 10 \mathrm{~min}$, and 50\%). Hence, the response surface modeling could be applied effectively to predict the enrichment of phenolic compounds from "Xichang" olive leaves.

\subsection{Quantification of Phenolic Compounds}

Under optimized conditions, samples of phenolic extracts of aged and young leaves were harvested from the six olive cultivars in different seasons. Seven main phenolic compounds of the sample were distinguished based on previous literature reports [29], and Figure 4A,B illustrate the chromatographic analysis of the standard mixture and representative sample from the "Arbequina" cultivar in January, April, July, and October. The levels of phenolic compounds between the aged and young leaves from January to December were detected using methods previously established in our lab [20].

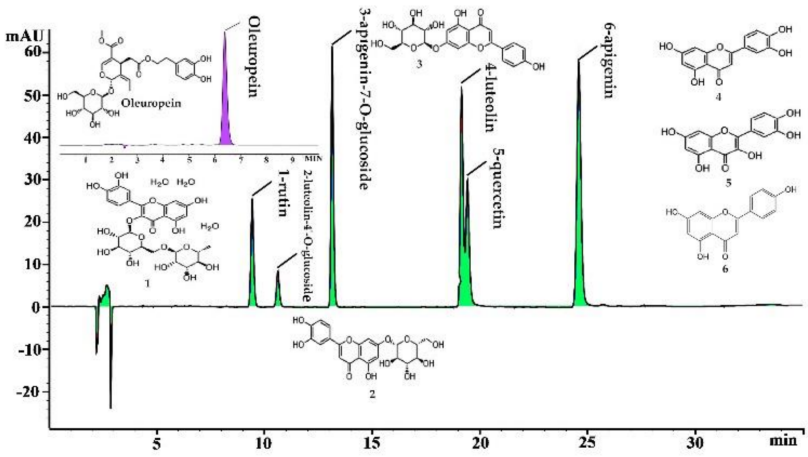

(A)

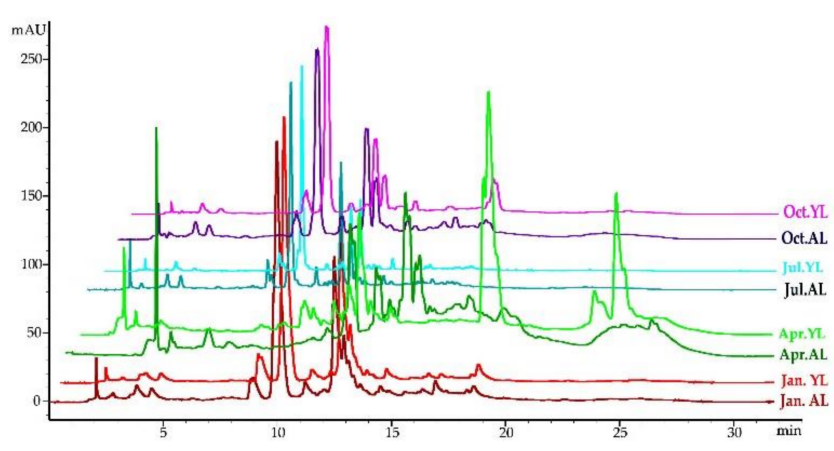

(B)

Figure 4. High-performance liquid chromatography (HPLC) chromatograms of phenolic compounds: (A) mixture standard; (B) samples from the aged and young leaves (AL and YL) in January, April, July, and October.

\subsubsection{Effect of Leaf Age and Season on Phenolic Compound Contents}

Table 3 shows that the TPC differed significantly between the aged and young leaves all year round, varying from 35.96 to $168.37 \mathrm{mg} / \mathrm{g} \mathrm{DM}$, and the level in the young leaves was higher than in the aged leaves. The highest TPC was obtained in January $(168.37 \mathrm{mg} / \mathrm{g}$ $\mathrm{DM})$ or December $(133.25 \mathrm{mg} / \mathrm{g} \mathrm{DM})$, whereas the lowest concentration was detected in April $(35.96 \mathrm{mg} / \mathrm{g}$ DM) or September $(78.15 \mathrm{mg} / \mathrm{g} \mathrm{DM})$. This seasonal change trend in TPC in the olive leaves, increasing from October and reaching higher levels in December, was also reported by Talhaoui et al., and verified our previous research results [20,30]. 
Table 3. Quantification of the main phenolic compounds in both aged and young leaves from January to December *.

\begin{tabular}{|c|c|c|c|c|c|c|c|c|c|}
\hline Months & LA & TPC & OEC & 1 & 2 & 3 & 4 & 5 & 6 \\
\hline \multirow{2}{*}{ January } & $\mathrm{AL}$ & $167.58 \pm 8.22^{a}$ & $33.89 \pm 2.61 \mathrm{hi}$ & $0.40 \pm 0.162^{\text {hijkl }}$ & $39.63 \pm 2.88^{\text {cde }}$ & $2.03 \pm 0.15^{\mathrm{efg}}$ & $0.048 \pm 0.006^{a}$ & $0.020 \pm 0.002^{\text {efg }}$ & nd \\
\hline & $\mathrm{YL}$ & $168.37 \pm 7.99^{\mathrm{a}}$ & $67.57 \pm 0.71^{\mathrm{e}}$ & $1.24 \pm 0.164^{b}$ & $49.58 \pm 5.72^{b}$ & $2.96 \pm 0.33 \mathrm{bc}$ & $0.057 \pm 0.007^{\mathrm{a}}$ & $0.425 \pm 0.005^{b c}$ & nd \\
\hline \multirow{2}{*}{ February } & $\mathrm{AL}$ & $89.27 \pm 5.14 \mathrm{gh}$ & $22.99 \pm 1.68^{\mathrm{ijk}}$ & $0.20 \pm 0.003^{\operatorname{lm}}$ & $47.95 \pm 0.69 \mathrm{bc}$ & $2.11 \pm 0.03^{\text {ef }}$ & $0.009 \pm 0.001^{\operatorname{defg}}$ & $0.014 \pm 0.003^{\mathrm{fg}}$ & nd \\
\hline & $\mathrm{YL}$ & $93.12 \pm 0.78 \mathrm{gh}$ & $44.65 \pm 1.52 \mathrm{fg}$ & $0.26 \pm 0.015^{\mathrm{klm}}$ & $37.78 \pm 2.36^{\text {def }}$ & $1.93 \pm 0.12$ efgh & $0.023 \pm 0.003 \mathrm{bc}$ & $0.113 \pm 0.019^{a}$ & $0.017 \pm 0.001$ \\
\hline \multirow{2}{*}{ March } & $\mathrm{AL}$ & $96.88 \pm 5.51^{\mathrm{fg}}$ & $21.38 \pm 3.26^{\mathrm{jkl}}$ & $0.20 \pm 0.022^{\operatorname{lm}}$ & $28.35 \pm 3.39$ fghi & $1.82 \pm 0.21 \mathrm{fgh}$ & $0.011 \pm 0.001^{\text {cdefg }}$ & $0.010 \pm 0.001^{\mathrm{fg}}$ & nd \\
\hline & YL & $118.75 \pm 2.04$ bcde & $89.16 \pm 12.45^{c}$ & $0.29 \pm 0.017 \mathrm{klm}$ & $41.65 \pm 2.69 \mathrm{bcd}$ & $1.63 \pm 0.10$ ghi & $0.018 \pm 0.002$ cde & $0.105 \pm 0.009 \mathrm{ab}$ & nd \\
\hline \multirow{2}{*}{ April } & $\mathrm{AL}$ & $47.36 \pm 5.67^{\mathrm{i}}$ & $74.74 \pm 5.59 \mathrm{de}$ & $0.32 \pm 0.227^{\mathrm{jklm}}$ & nd & $0.30 \pm 0.12^{1}$ & $0.005 \pm 0.001$ efg & $0.009 \pm 0.004^{\mathrm{fg}}$ & $0.190 \pm 0.132$ \\
\hline & YL & $35.96 \pm 4.13^{i}$ & $14.72 \pm 0.41 \mathrm{kl}$ & nd & nd & $0.28 \pm 0.01^{1}$ & $0.018 \pm 0.006^{\mathrm{bcd}}$ & $0.067 \pm 0.025$ abcde & $0.030 \pm 0.002$ \\
\hline \multirow{2}{*}{ May } & $\mathrm{AL}$ & $111.25 \pm 3.27 \mathrm{def}$ & $25.56 \pm 0.35^{\mathrm{ijk}}$ & $0.16 \pm 0.008^{\mathrm{m}}$ & $25.67 \pm 0.91$ ghij & $1.64 \pm 0.05$ ghi & $0.010 \pm 0.002^{\text {cdefg }}$ & nd & nd \\
\hline & YL & $117.67 \pm 2.62$ bcde & $47.03 \pm 0.85 \mathrm{fg}$ & $0.19 \pm 0.035^{\mathrm{lm}}$ & $19.81 \pm 0.50$ hij & $0.99 \pm 0.04^{\mathrm{jk}}$ & $0.055 \pm 0.010^{\mathrm{a}}$ & nd & nd \\
\hline \multirow{2}{*}{ June } & $\mathrm{AL}$ & $114.85 \pm 2.62^{\text {cde }}$ & $16.38 \pm 0.18^{\mathrm{kl}}$ & $0.28 \pm 0.015^{\mathrm{klm}}$ & $29.29 \pm 1.20^{\mathrm{fgh}}$ & $1.92 \pm 0.11^{\text {efgh }}$ & $0.011 \pm 0.002^{\text {cdefg }}$ & $0.004 \pm 0.001 \mathrm{~g}$ & nd \\
\hline & YL & $121.47 \pm 2.41 \mathrm{bcd}$ & $148.10 \pm 6.63^{a}$ & $0.27 \pm 0.003 \mathrm{klm}$ & $18.01 \pm 9.32^{j}$ & $1.53 \pm 0.04 \mathrm{hi}$ & $0.031 \pm 0.009^{\mathrm{b}}$ & $0.100 \pm 0.039^{a b}$ & $0.017 \pm 0.001$ \\
\hline \multirow{2}{*}{ July } & $\mathrm{AL}$ & $88.67 \pm 5.33 \mathrm{gh}$ & $22.06 \pm 0.09 \mathrm{jk}$ & $0.59 \pm 0.046^{\text {efgh }}$ & $27.91 \pm 1.77$ fghi & $2.05 \pm 0.15^{\text {efg }}$ & $0.006 \pm 0.003^{\text {defg }}$ & $0.004 \pm 0.001 \mathrm{~g}$ & nd \\
\hline & $\mathrm{YL}$ & $90.47 \pm 7.59 \mathrm{gh}$ & $90.23 \pm 0.62^{c}$ & $0.46 \pm 0.024^{h i j k l}$ & $31.69 \pm 2.12$ efg & $1.69 \pm 0.10$ ghi & $0.012 \pm 0.003$ cdefg & $0.043 \pm 0.016^{\text {cdefg }}$ & nd \\
\hline August & $\mathrm{YL}$ & $124.56 \pm 1.41^{\mathrm{bcd}}$ & $78.17 \pm 0.38^{d}$ & $0.62 \pm 0.035^{\text {defg }}$ & $31.27 \pm 1.08$ efg & $1.51 \pm 0.11^{\mathrm{ij}}$ & $0.031 \pm 0.002^{b}$ & $0.073 \pm 0.009^{a b c}$ & $0.019 \pm 0.002$ \\
\hline \multirow{2}{*}{ September } & $\mathrm{AL}$ & $78.15 \pm 5.83^{h}$ & $16.26 \pm 0.63^{\mathrm{kl}}$ & $0.54 \pm 0.044^{\text {fghi }}$ & $20.88 \pm 1.80^{\text {hij }}$ & $1.32 \pm 0.09^{\mathrm{ij}}$ & $0.005 \pm 0.001$ efg & $0.007 \pm 0.074^{g}$ & nd \\
\hline & YL & $103.08 \pm 3.38^{\text {efg }}$ & $41.62 \pm 0.23 \mathrm{gh}$ & $0.34 \pm 0.038^{\mathrm{ijklm}}$ & $18.69 \pm 2.15^{\mathrm{ij}}$ & $0.99 \pm 0.11^{j k}$ & $0.004 \pm 0.001 \mathrm{fg}$ & $0.058 \pm 0.009$ bcdef & nd \\
\hline \multirow{2}{*}{ October } & $\mathrm{AL}$ & $97.18 \pm 7.54 \mathrm{fg}$ & $10.58 \pm 0.09^{1}$ & $0.52 \pm 0.060$ fghij & $9.07 \pm 1.39^{\mathrm{k}}$ & $0.65 \pm 0.09 \mathrm{kl}$ & $0.006 \pm 0.001$ efg & $0.009 \pm 0.0 .006^{\mathrm{fg}}$ & nd \\
\hline & YL & $129.07 \pm 3.43^{b c}$ & $52.78 \pm 0.81^{\mathrm{f}}$ & $0.90 \pm 0.026^{\mathrm{c}}$ & $19.28 \pm 0.81^{\mathrm{ij}}$ & $0.92 \pm 0.05^{\mathrm{k}}$ & $0.010 \pm 0.001^{\text {cdefg }}$ & $0.059 \pm 0.014^{\text {bcdef }}$ & nd \\
\hline \multirow{2}{*}{ November } & $\mathrm{AL}$ & $91.64 \pm 2.51$ gh & $15.50 \pm 1.32 \mathrm{kl}$ & $0.81 \pm 0.028^{\mathrm{cd}}$ & $31.67 \pm 1.36^{\mathrm{efg}}$ & $1.85 \pm 0.09$ efgh & $0.008 \pm 0.001^{\text {defg }}$ & $0.032 \pm 0.003^{\text {defg }}$ & nd \\
\hline & $\mathrm{YL}$ & $117.20 \pm 3.781$ bcde & $106.49 \pm 2.11^{b}$ & $1.51 \pm 0.095^{\mathrm{a}}$ & $62.33 \pm 4.16^{\mathrm{a}}$ & $3.23 \pm 0.22 \mathrm{ab}$ & $0.002 \pm 0.001 \mathrm{~g}$ & $0.099 \pm 0.033^{\mathrm{ab}}$ & nd \\
\hline \multirow{2}{*}{ December } & $\mathrm{AL}$ & $113.611 \pm 11.93^{\text {cde }}$ & $10.29 \pm 0.12^{\text {gh }}$ & $0.75 \pm 0.006^{\text {cde }}$ & $34.44 \pm 0.43^{\text {defg }}$ & $2.24 \pm 0.03 \mathrm{de}$ & $0.005 \pm 0.001$ efg & $0.017 \pm 0.002^{\mathrm{fg}}$ & nd \\
\hline & $\mathrm{YL}$ & $133.25 \pm 3.42^{b}$ & $24.33 \pm 0.73^{\mathrm{ijk}}$ & $1.29 \pm 0.013^{b}$ & $47.75 \pm 0.67 \mathrm{bc}$ & $3.56 \pm 0.06^{\mathrm{a}}$ & $0.017 \pm 0.003^{\text {cdef }}$ & $0.088 \pm 0.011^{\mathrm{abc}}$ & nd \\
\hline
\end{tabular}

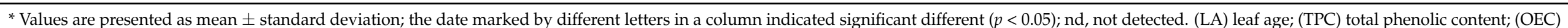
oleuropein content; (1) rutin; (2) luteolin-4'-O-glucoside; (3) apigenin-7-O-glucoside; (4) luteolin; (5) quercetin; (6) apigenin. 
Oleuropein and luteolin-4'-O-glucoside were the most abundant phenolic components, followed by apigenin-7-O-glucoside and rutin, whereas luteolin, quercetin, and apigenin were the least abundant (Table 3). In the published literature, oleuropein was found to begin accumulating in the leaves with an intense green color, with yellow or green-yellowish leaves displaying significantly lower levels [31]. In this study, the oleuropein content of the aged and young leaves followed this reported trend, except for April, where a high level was detected in the young leaves. In terms of seasonal change, the OEC changed drastically in summer and autumn. Especially in June and November, a sharp decline in OEC was observed in the mature and senescent olive leaves, decreasing from 148.10 to $16.38 \mathrm{mg} / \mathrm{g} \mathrm{DM}$ and from 106.49 to $15.50 \mathrm{mg} / \mathrm{g}$ DM, respectively. Meanwhile, rutin, luteolin-4'-O-glucoside, and apigenin-7-O-glucoside exhibited fluctuations from 1.51 to $0.16 \mathrm{mg} / \mathrm{g} \mathrm{DM}$, from 62.33 to $18.01 \mathrm{mg} / \mathrm{g} \mathrm{DM}$, and from 3.56 to $0.28 \mathrm{mg} / \mathrm{g} \mathrm{DM}$, respectively. Notably, these three compounds were much more unstable in April, with the content being low or not even detected. This phenomenon has already been explored by Wu et al., who reported that April, June, and September were the developmental periods of the shoots in spring, summer and autumn in Xichang [14], but January and November were associated with very slow growth of the leaves and near-dormancy, which would be an important factor affecting the levels of these compounds [12]. Regarding luteolin and quercetin, their concentration was relatively low, only amounting to 0.057 to $0.002 \mathrm{mg} / \mathrm{g}$ DM and 0.113 to $0.004 \mathrm{mg} / \mathrm{g} \mathrm{DM}$, respectively, throughout the entire year. Compared with the aged leaves, higher levels of luteolin were noted in the young leaves from February to August, while apigenin was found in low amounts in the young leaves in February, June, and August, which was also determined in different parts of "Chemlali" variety with different development stages by Abaza et al. [32].

Consequently, seasonal variations markedly affected these seven components in the aged and young leaves, with the largest monthly fluctuation observed in summer and autumn, and thus the optimum sampling time was in spring and winter. Meanwhile, the content of these compounds increased in the young leaves and declined in the aged leaves. These changes in phenolic levels in the olive leaves might be closely related to the combination of climate conditions and nutrient cycling (buds, flowers, and fruits), as suggested by Malik and Bradford and Xiao et al. [33,34].

\subsubsection{Influence of Leaf Age and Cultivars on Phenolic Compound Contents}

The variation in the major phenolic components in the aged and young leaves of the six cultivars is presented in Table 4 . The TPC varied extensively with the different olive varieties, ranging from 151.04 to $123.18 \mathrm{mg} / \mathrm{g} \mathrm{DM}$, and the greatest levels were discovered in the young leaves of "Koroneiki" and "Jiufeng", whereas evidently lower levels were presented in the aged leaves of "Koroneiki" and "Arbeqoina". This general trend, with lower contents in the aged leaves, was also detected for most of the seven phenolic compounds. For instance, oleuropein, rutin, luteolin, and quercetin in all of the samples, with values of $18.64,1.74,0.006$, and $0.006 \mathrm{mg} / \mathrm{g} \mathrm{DM}$, respectively, displayed minimum contents in the aged leaves. With the exception of "Frantioio", apigenin was hard to detect in the aged leaves, or was barely detectable. On the contrary, luteolin-4'-Oglucoside and apigenin-7-O-glucoside were highest in the aged leaves. This change in the aged leaves was previously reported by Ranalli et al., who highlighted that color/age and genetic factors markedly modified the oleuropein content of Italian olive leaves [31]. 
Table 4. Quantification of the main phenolic compounds in both aged and young leaves (AL and YL) in six Chinese olive varieties*.

\begin{tabular}{|c|c|c|c|c|c|c|c|c|c|}
\hline Cultivars & LA & TPC & OEC & 1 & 2 & 3 & 4 & 5 & 6 \\
\hline \multirow{2}{*}{ Salonenque } & $\mathrm{AL}$ & $127.68 \pm 3.43^{\mathrm{d}}$ & $45.86 \pm 0.25^{g}$ & $2.15 \pm 0.032^{\mathrm{ij}}$ & $43.26 \pm 1.74 \mathrm{bcd}$ & $2.75 \pm 0.13^{c}$ & $0.015 \pm 0.002^{\mathrm{e}}$ & $0.014 \pm 0.003^{\mathrm{fg}}$ & \\
\hline & YL & $141.60 \pm 0.26^{b}$ & $50.48 \pm 0.32^{f}$ & $2.92 \pm 0.131 \mathrm{gh}$ & $22.80 \pm 0.80^{\mathrm{f}}$ & $1.58 \pm 0.05^{\mathrm{e}}$ & $0.039 \pm 0.001^{\mathrm{a}}$ & $0.030 \pm 0.001^{\mathrm{e}}$ & $0.034 \pm 0.004^{b}$ \\
\hline \multirow{2}{*}{ Arbeqoina } & $\mathrm{AL}$ & $123.18 \pm 1.74 \mathrm{de}$ & $43.41 \pm 0.82 \mathrm{gh}$ & $7.70 \pm 0.126^{c}$ & $43.24 \pm 0.36^{\mathrm{bcd}}$ & $3.85 \pm 0.0 .01^{\mathrm{a}}$ & $0.013 \pm 0.001^{\mathrm{e}}$ & $0.012 \pm 0.001 \mathrm{fg}$ & \\
\hline & $\mathrm{YL}$ & $142.92 \pm 0.67^{b}$ & $67.94 \pm 0.82^{d}$ & $10.23 \pm 0.060^{\mathrm{a}}$ & $45.26 \pm 0.66^{\mathrm{bcd}}$ & $3.63 \pm 0.15^{\mathrm{ab}}$ & $0.035 \pm 0.002^{a}$ & $0.080 \pm 0.010^{c}$ & $0.022 \pm 0.001^{\mathrm{c}}$ \\
\hline \multirow{2}{*}{ Koroneiki } & $\mathrm{AL}$ & $123.66 \pm 0.03$ de & $18.64 \pm 0.33^{j}$ & $2.99 \pm 0.045^{\text {gh }}$ & $52.65 \pm 1.30^{a}$ & $2.78 \pm 0.03^{c}$ & $0.017 \pm 0.001 \mathrm{de}$ & $0.012 \pm 0.001 \mathrm{fg}$ & \\
\hline & YL & $146.45 \pm 0.82^{\mathrm{ab}}$ & $121.46 \pm 1.81^{b}$ & $3.99 \pm 0.101^{\mathrm{e}}$ & $35.49 \pm 1.80^{\mathrm{e}}$ & $2.17 \pm 0.18^{\mathrm{d}}$ & $0.036 \pm 0.002^{\mathrm{a}}$ & $0.095 \pm 0.003^{b}$ & \\
\hline \multirow{2}{*}{ Jiufeng } & $\mathrm{AL}$ & $141.56 \pm 2.01^{b}$ & $58.26 \pm 0.13^{\mathrm{e}}$ & $1.74 \pm 0.110^{\mathrm{j}}$ & $48.75 \pm 2.71^{\mathrm{ab}}$ & $2.29 \pm 0.03^{\mathrm{d}}$ & $0.006 \pm 0.002^{f}$ & $0.014 \pm 0.001 \mathrm{fg}$ & \\
\hline & YL & $151.04 \pm 0.43^{\mathrm{a}}$ & $136.54 \pm 2.73^{a}$ & $3.46 \pm 0.226^{\mathrm{ef}}$ & $39.59 \pm 0.57 \mathrm{de}$ & $2.09 \pm 0.05^{\mathrm{d}}$ & $0.023 \pm 0.001^{c}$ & $0.072 \pm 0.003^{c}$ & $0.020 \pm 0.001^{\mathrm{c}}$ \\
\hline \multirow{2}{*}{ Frantioio } & $\mathrm{AL}$ & $127.71 \pm 2.21^{\mathrm{d}}$ & $25.59 \pm 0.34^{\mathrm{i}}$ & $2.61 \pm 0.211 \mathrm{hi}$ & $48.53 \pm 2.01 \mathrm{ab}$ & $3.73 \pm 0.0 .16^{\mathrm{ab}}$ & $0.023 \pm 0.0 .001^{c}$ & $0.006 \pm 0.001 \mathrm{~g}$ & $0.043 \pm 0.005^{\mathrm{a}}$ \\
\hline & YL & $125.00 \pm 2.85$ de & $42.69 \pm 0.63^{h}$ & $1.84 \pm 0.035^{\mathrm{j}}$ & $46.25 \pm 5.38^{b c}$ & $2.45 \pm 0.25^{\mathrm{cd}}$ & $0.028 \pm 0.0 .002^{b}$ & $0.050 \pm 0.0 .005^{d}$ & \\
\hline \multirow{2}{*}{ Arbosana } & $\mathrm{AL}$ & $126.73 \pm 1.47^{\mathrm{d}}$ & $44.53 \pm 0.41^{g}$ & $7.06 \pm 0.432^{d}$ & $43.70 \pm 1.01^{b c d}$ & $3.39 \pm 0.15^{b}$ & $0.013 \pm 0.0 .001^{\mathrm{e}}$ & $0.018 \pm 0.0 .003^{\mathrm{f}}$ & \\
\hline & YL & $135.10 \pm 2.82^{c}$ & $95.83 \pm 0.96^{c}$ & $9.25 \pm 0.140^{b}$ & $40.40 \pm 2.33^{\text {cde }}$ & $1.67 \pm 1.26^{\mathrm{e}}$ & $0.021 \pm 0.0 .002^{\mathrm{cd}}$ & $0.108 \pm 0.004^{\mathrm{a}}$ & $0.020 \pm 0.002^{c}$ \\
\hline
\end{tabular}

* The date marked by different letters in a column indicated significant different $(p<0.05)$. 
As mentioned earlier, oleuropein was present at higher levels in the younger leaves, including in "Jiufeng" (136.54 mg/g DM), "Koroneiki" (121.46 mg/g DM), and "Arbosana" $(95.83 \mathrm{mg} / \mathrm{g} \mathrm{DM})$. Among the six cultivars, "Koroneiki" exhibited higher levels of luteolin$4^{\prime}$-O-glucoside $(52.65 \mathrm{mg} / \mathrm{g} \mathrm{DM})$ and luteolin $(0.036 \mathrm{mg} / \mathrm{g} \mathrm{DM})$ and a lower content of oleuropein $(18.64 \mathrm{mg} / \mathrm{g} \mathrm{DM})$. Another remarkable finding was that "Arbeqoina" presented the highest concentrations of rutin $(10.23 \mathrm{mg} / \mathrm{g} \mathrm{DM})$ and apigenin-7-O-glucoside $(3.85 \mathrm{mg} / \mathrm{g} \mathrm{DM})$ and the lowest TPC (123.18 mg/g DM). In addition, "Arbosana" possessed the greatest amount of quercetin $(0.108 \mathrm{mg} / \mathrm{g} \mathrm{DM})$, while "Frantioio" presented the lowest $(0.006 \mathrm{mg} / \mathrm{g}$ DM). Compared to the aged leaves of "Frantioio", no apigenin was detected in both the aged and young leaves of "Koroneiki", while other varieties were only found in the young leaves. In summary, the seven phenolic components in the leaves of the six olive cultivars matched those from other cultivars, such as Portuguese cultivars studied by Vinha et al., and Spanish cultivars reported by Talhaoui et al $[29,35]$.

\subsection{Antioxidant Activity of TPs and Oleuropein}

At optimum UAE conditions, samples of young leaves from the "Picual" cultivar in February were concentrated by a rotary evaporator and dried at $45^{\circ} \mathrm{C}$ in a vacuum drying oven to obtain the phenol extract; the extract was fractionated on a Sephadex LH-20 to obtain the purified oleuropein ( $70 \%$ oleuropein), which was investigated for its antioxidant activity using in vitro assays (Figure 5 and Table 5).
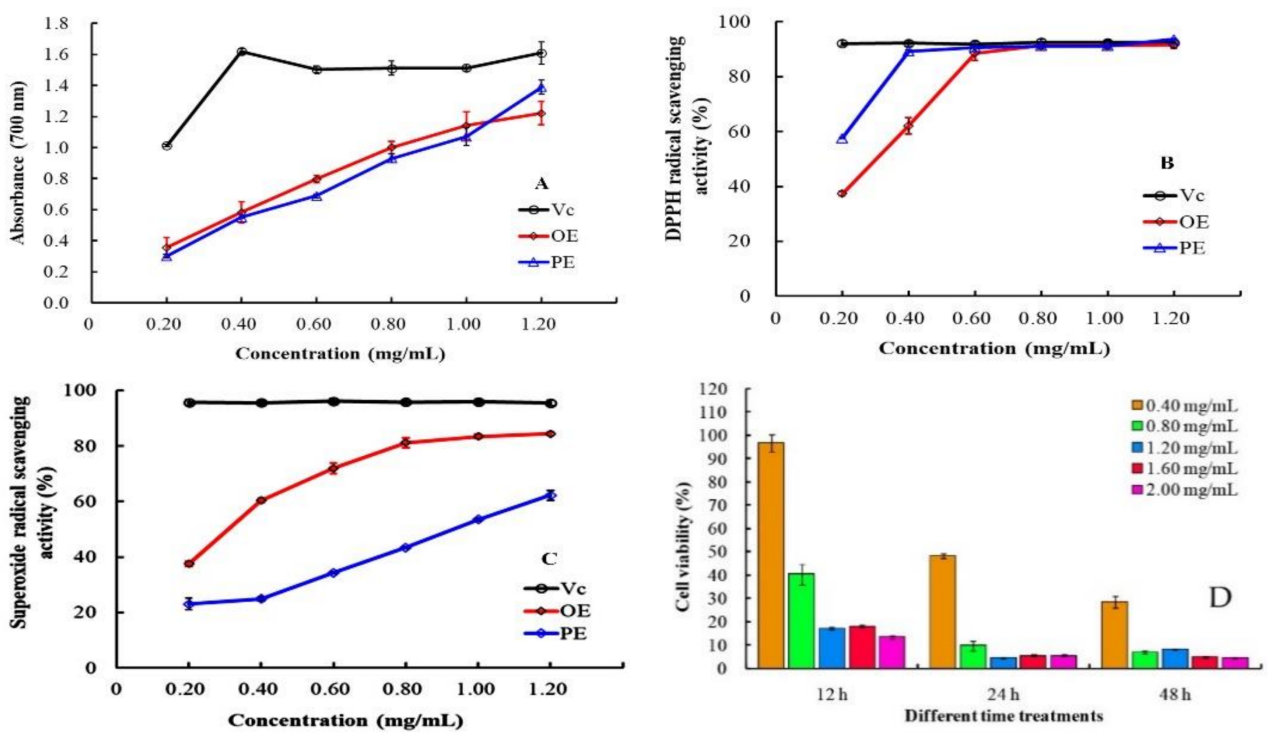

Figure 5. Antioxidant and anticancer activities of samples from Chinese olive leaf at different concentra-tions. (A) Reducing power; (B) DPPH radical scavenging activity; (C) Superoxide radical scav-enging activity; (D) Dose and time response of oleuropein-treated HeLa cells.

Table 5. $\mathrm{EC}_{50}$ values $(\mathrm{mg} / \mathrm{mL})$ of the phenol extract $(\mathrm{PE})$ and oleuropein $(\mathrm{OE})$ from Chinese olive leaves.

\begin{tabular}{ccccc}
\hline \multirow{2}{*}{ Antioxidant Activities } & \multicolumn{2}{c}{$\mathrm{EC}_{\mathbf{5 0}}(\mathrm{mg} / \mathrm{mL})$} & \multirow{2}{*}{ Cell Viability } & $\mathrm{EC}_{\mathbf{5 0}}(\mathrm{mg} / \mathbf{m L})$ \\
\cline { 2 - 3 } \cline { 5 - 5 } & $\mathbf{P E}$ & $\mathrm{OE}$ & & $\mathrm{OE}$ \\
\hline Reducing power & $0.33 \pm 0.046$ & $0.29 \pm 0.003$ & $12 \mathrm{~h}$ & $0.82 \pm 0.119$ \\
DPPH radicals & $0.14 \pm 0.001$ & $0.27 \pm 0.016$ & $24 \mathrm{~h}$ & $0.36 \pm 0.072$ \\
Superoxide radicals & $0.93 \pm 0.003$ & $0.29 \pm 0.001$ & $48 \mathrm{~h}$ & $0.19 \pm 0.020$ \\
\hline
\end{tabular}

Reducing power is usually associated with the presence of reducers, which exert antioxidant action by breaking the free-radical chain by donating a hydrogen atom [36]. From Figure 5A, the absorbances of PE and OE increased with increasing concentration, 
which indicated that the reducing power presented concentration-dependent activity. As shown in Table 5, the $\mathrm{EC}_{50}$ values of $\mathrm{OE}(0.29 \mathrm{mg} / \mathrm{mL})$ demonstrated higher reducing capability than that of PE $(0.33 \mathrm{mg} / \mathrm{mL})$, although both were weaker than Vc. Perhaps the OE may effectively contribute to electron reduction due to its radical scavenging capacities [37]. To gain insight into the radical-scavenging capacity, the PE and OE were further tested. At $0.20-0.60 \mathrm{mg} / \mathrm{mL}$, the scavenging ability of DPPH radicals was heightened with the increasing concentration of $\mathrm{PE}$ and $\mathrm{OE}$, reaching about $90 \%$ at $0.6 \mathrm{mg} / \mathrm{mL}$ (Figure $5 \mathrm{~B}$ ). When the concentration of $\mathrm{PE}$ and $\mathrm{OE}$ was increased to $1.20 \mathrm{mg} / \mathrm{mL}$, the DPPH scavenging abilities were about $92 \%$, nearly equal to that of Vc. Furthermore, the lower $\mathrm{EC}_{50}$ value of $\mathrm{PE}(0.14 \mathrm{mg} / \mathrm{mL})$ revealed a higher DPPH scavenging effect than that of $\mathrm{OE}(0.27 \mathrm{mg} / \mathrm{mL})$, which was probably attributed to the synergy among flavonoids, oleuropeosids, and phenols [38]. However, the $\mathrm{EC}_{50}$ value of $\mathrm{PE}$ on superoxide radicals was as high as $0.93 \mathrm{mg} / \mathrm{mL}$, which was clearly higher than that of $\mathrm{OE}(0.29 \mathrm{mg} / \mathrm{mL})$, implying that the OE showed stronger ability to scavenge superoxide anions (Table 5). Varying concentrations of the PE and $\mathrm{OE}$ resulted in different scavenging activities; at $1.20 \mathrm{mg} / \mathrm{mL}$, the scavenging efficiency of PE on superoxide radicals was below that of $\mathrm{Vc}_{\mathrm{c}}(95.49 \%)$ and OE $(84.44 \%)$, but a dose-effect relationship between the concentration and superoxide scavenging efficiency was observed (Figure 5C). These findings were consistent with the results for stoned table olives [37], and a higher antioxidant effect of $\mathrm{OE}$ was detected compared with the PE, which has been discussed by Visioli et al. who reported that OE was a potent scavenger of superoxide radicals [39].

\subsection{Cell Viability of Oleuropein}

HeLa is one of the most used cell lines in biomedical research. Studies have shown that oleuropein, the main component of olive leaf extracts, inhibited growth and induced apoptosis in HeLa cells in the range of $150-200 \mu \mathrm{M}$ at $24 \mathrm{~h}$ [7]. In addition, in previous study, we observed that PE-treated $(0-800 \mu \mathrm{g} / \mathrm{mL})$ normal cells were unharmed and also has no inhibitory effect on HeLa cells [20]. Therefore, oleuropein was tested for its inhibitory effect on HeLa cells, and the effective dose and time of oleuropein were evaluated in vitro by CCK- 8 analysis. As shown in Figure 5D, cell viability dropped in the first $24 \mathrm{~h}$ at the range of $0.40-2.00 \mathrm{mg} / \mathrm{mL}$, and as the treatment time was prolonged to 24 or $48 \mathrm{~h}$, a similar dose-dependent result was found. The orders of $\mathrm{EC}_{50}(\mathrm{mg} / \mathrm{mL})$ were $48 \mathrm{~h}(0.19)<24 \mathrm{~h}$ $(0.36)<12 \mathrm{~h}(0.82)$, which showed a dramatic reduction in cell vitality with the extension of time (Table 5). In addition, when the concentration of OE reached $0.80 \mathrm{mg} / \mathrm{mL}$, a long incubation period ( 24 or $48 \mathrm{~h}$ ) caused a significant decrease in cell viability of $9.90 \%$ and $7.37 \%$ at $24 \mathrm{~h}$ and $48 \mathrm{~h}$, respectively. In a similar study, such a dramatic increase in the death of breast cancer cells was assumed to be the result of prolonged treatment time [40]. This finding might be because oleuropein inhibited the proliferation of HeLa cells. The effect of oleuropein-treated HeLa cells was dose and time dependent, but it is necessary to further study its signal pathway and molecular mechanism.

\section{Conclusions}

In the present study, a four-level BBD experiment based on RSM was used to optimize the extraction conditions of TP and $\mathrm{OE}$ from Chinese olive leaves. The combination of a liquid-solid ratio of $30 \mathrm{~mL} / \mathrm{g}$, ultrasound power of $260 \mathrm{~W}$, extraction time of $30 \mathrm{~min}$, and an ethanol concentration of $50 \%$ was found to obtain the highest TPC (197.32 mg/g DM) and OEC $(74.35 \mathrm{mg} / \mathrm{g} \mathrm{DM})$. There was seasonal variation in the phenolic components between the aged and young leaves from January to December, and a considerable difference in phenolic levels among the six Chinese cultivars was observed, with the leaves of the "Koroneiki" and "Jiufeng" varieties containing abundant phenols. Among the seven components, oleuropein and luteolin-4'-O-glucoside were highest, apigenin-7-O-glucoside and rutin were the second-most abundant, and luteolin and quercetin were the lowest. The main components of the young leaves remained relatively constant in spring and winter, whereas these compounds showed distinct changes in summer and autumn. The 
in vitro experiment demonstrated that the superoxide radical scavenging capacity of $\mathrm{OE}$ was superior to that of PE, but both exhibited similar antioxidant activities on DPPH and reducing power. Additionally, after $48 \mathrm{~h}$ of exposure, the cell activity against HeLa cells decreased dramatically with increasing $\mathrm{OE}$ concentration. Our results confirmed the good antioxidant and anticancer effect of Chinese olive leaves. Due to the multiple properties of these leaves (antioxidant, anti-cancer, therapeutical, and functional), Chinese olive leaves have a great potential for medicinal, cosmetic, and pharmaceuticaluses, and can be applied in functionalizing/developing a wide range of food products.

Author Contributions: Conceptualization, all authors; data curation, S.S.; investigation, J.Q.; methodology, Z.X. project administration, C.D.; software, S.F.; writing—original draft, B.W.; writing—review and editing, T.C. All authors have read and agreed to the published version of the manuscript.

Funding: This work was supported by the Doctoral Scientific Research Foundation of China West Normal University (grant numbers 20E046); the Bureau of Science \& Technology Nanchong City in Sichuan Province of China (grant number 19YFZJ0108); the Education Department in Sichuan Province of China (grant number SDJJ1915); Sichuan Science and Technology Program of China (grant number 2020YFH0207).

Institutional Review Board Statement: Not applicable.

Informed Consent Statement: Not applicable.

Data Availability Statement: The data that support the findings of this study are available from the corresponding author upon reasonable request.

Acknowledgments: The authors wish to thank to the the Liangshan Zhongze New Tech-Development Company for providing some samples. The authors are also grateful to Siyuan Luo, Chunyan Zhang and Li Liu at our laboratory for their valuable assistance.

Conflicts of Interest: The authors declare no conflict of interest.

\section{References}

1. Wu, X.; Zhang, Y. Calculation of market power in the import of China's olive oil market and factors under the imperfectly competitive market. China Oils Fats 2021, 46, 5-9.

2. Paulo, F.; Santos, L. Deriving valorization of phenolic compounds from olive oil by-products for food applications through microencapsulation approaches: A comprehensive review. Crit. Rev. Food Sci. Nutr. 2020, 61, 1-26. [CrossRef] [PubMed]

3. Xie, P. Study on high-value utilization of olive leaf and its meachanism. Ph.D. Thesis, Chinese Academic of Forestry, Beijing, China, May 2015.

4. Irakli, M.; Chatzopoulou, P.; Ekateriniadou, L. Optimization of ultrasound-assisted extraction of phenolic compounds: Oleuropein, phenolic acids, phenolic alcohols and flavonoids from olive leaves and evaluation of its antioxidant activities. Ind. Crop. Prod. 2018, 124, 382-388. [CrossRef]

5. Markhali, F.S.; Teixeira, J.A.; Rocha, C.M. Olive tree leaves-A source of valuable active compounds. Processes 2020, 8, 1177. [CrossRef]

6. Hamdi, H.K.; Castellon, R. Oleuropein, a non-toxic olive iridoid, is an anti-tumor agent and cytoskeleton disruptor. Biochem. Biophys. Res. Commun. 2005, 334, 769-778. [CrossRef]

7. Yao, J.; Wu, J.; Yang, X.; Yang, J.; Zhang, Y.; Du, L. Oleuropein induced apoptosis in HeLa cells via a mitochondrial apoptotic cascade associated with activation of the c-Jun NH2-terminal kinase. J. Pharmacol. Sci. 2014, 125, 300-311. [CrossRef]

8. Seçme, M.; Eroğlu, C.; Dodurga, Y.; Bağcl, G. Investigation of anticancer mechanism of oleuropein via cell cycle and apoptotic pathways in SH-SY5Y neuroblastoma cells. Gene 2016, 585, 93-99. [CrossRef]

9. Özcan, M.M.; Matthäus, B. A review: Benefit and bioactive properties of olive (Olea europaea L.) leaves. Eur. Food Res. Technol. 2017, 243, 89-99. [CrossRef]

10. Guo, Z.; Jia, X.; Zheng, Z.; Lu, X.; Zheng, Y.; Zheng, B.; Xiao, J. Chemical composition and nutritional function of olive (Olea europaea L.): A review. Phytochem. Rev. 2018, 17, 1091-1110. [CrossRef]

11. Žuntar, I.; Putnik, P.; Bursać Kovačević, D.; Nutrizio, M.; Šupljika, F.; Poljanec, A.; Dubrović, I.; Barba, F.J.; Režek Jambrak, A. Phenolic and antioxidant analysis of olive leaves extracts (Olea europaea L.) obtained by high voltage electrical discharges (HVED). Foods 2019, 8, 248. [CrossRef] 
12. Mert, C.; Barut, E. Quantitative seasonal changes in the leaf phenolic content related to the alternate-bearing patterns of olive (Olea europaea L. cv. Gemlik). J. Agric. Sci. Technol. 2018, 15, 995-1006.

13. Lama-Muñoz, A.; del Mar Contreras, M.; Espínola, F.; Moya, M.; de Torres, A.; Romero, I.; Castro, E. Extraction of oleuropein and luteolin-7-O-glucoside from olive leaves: Optimization of technique and operating conditions. Food Chem. 2019, 293, 161-168. [CrossRef]

14. Wu, Z.; Yue, G.; Zhu, Q.; Jiang, Y.; Tang, K.; Chen, H.; Yang, Z.; Huang, Q. Purification, dynamic changes and antioxidant activities of oleuropein in olive (Olea Europaea L.) leaves. J. Food Biochem. 2015, 39, 566-574.

15. Zhan, M.; Cheng, Z.; Su, G.; Wang, A.; Chen, H.; Yang, Z.; Shan, Z.; Huang, Q. Genetic relationships analysis of olive cultivars grown in China. Genet. Mol. Res. 2015, 2, 5958-5969. [CrossRef]

16. Yu, L.; Wang, Y.; Wu, G.; Jin, J.; Jin, Q.; Wang, X. Quality and composition of virgin olive oils from indigenous and European cultivars grown in China. J. Am. Oil Chem. Soc. 2020, 97, 341-353. [CrossRef]

17. Cheng, Z.; Zhan, M.; Yang, Z.; Zumstein, K.; Chen, H.; Huang, Q. The major qualitative characteristics of olive (Olea europaea L.) cultivated in southwest China. Front. Plant Sci. 2017, 8, 559. [CrossRef]

18. Lamprou, G.K.; Vlysidis, A.; Tzathas, K.; Vlyssides, A.G. Statistical optimization and kinetic analysis of the extraction of phenolic compounds from olive leaves. J. Chem. Technol. Biotechnol. 2020, 95, 457-465. [CrossRef]

19. Şahin, S.; Samli, R.; Tan, A.S.B.; Barba, F.J.; Chemat, F.; Cravotto, G.; Lorenzo, J.M. Solvent-free microwave-assisted extraction of polyphenols from olive tree leaves: Antioxidant and antimicrobial properties. Molecules 2017, 22, 1056. [CrossRef]

20. Wang, B.; Qu, J.; Feng, S.; Chen, T.; Yuan, M.; Huang, Y.; Liao, J.; Yang, R.; Ding, C. Seasonal variations in the chemical composition of Liangshan olive leaves and their antioxidant and anticancer activities. Foods 2019, 8, 657. [CrossRef]

21. Wang, B.; Qu, J.; Luo, S.; Feng, S.; Li, T.; Yuan, M.; Huang, Y.; Liao, J.; Yang, R.; Ding, C. Optimization of ultrasound-assisted extraction of flavonoids from olive (Olea europaea) leaves, and evaluation of their antioxidant and anticancer activities. Molecules 2018, 23, 2513. [CrossRef]

22. Zhang, Y.; Shen, Y.; Zhu, Y.; Xu, Z. Assessment of the correlations between reducing power, scavenging DPPH activity and anti-lipid-oxidation capability of phenolic antioxidants. LWT Food Sci. Technol. 2015, 63, 569-574. [CrossRef]

23. Oyaizu, M. Studies on products of browning reaction antioxidative activities of products of browning reaction prepared from glucosamine. Jpn. J. Nutr. Diet. 1986, 44, 307-315. [CrossRef]

24. Živković, J.; Šavikin, K.; Janković, T.; Ćujić, N.; Menković, N. Optimization of ultrasound-assisted extraction of polyphenolic compounds from pomegranate peel using response surface methodology. Sep. Purif. Technol. 2018, 194, 40-47. [CrossRef]

25. Martínez-Patiño, J.C.; Gullón, B.; Romero, I.; Ruiz, E.; Brnčić, M.; Žlabur, J.Š.; Castro, E. Optimization of ultrasound-assisted extraction of biomass from olive trees using response surface methodology. Ultrason. Sonochem. 2019, 51, 487-495. [CrossRef]

26. Goo, Y.T.; Park, S.Y.; Chae, B.R.; Yoon, H.Y.; Kim, C.H.; Choi, J.Y.; Song, S.H.; Choi, Y.W. Optimization of solid self-dispersing micelle for enhancing dissolution and oral bioavailability of valsartan using Box-Behnken design. Int. J. Pharm. 2020, 585, 119483. [CrossRef]

27. Wang, X.; Wu, Y.; Chen, G.; Yue, W.; Liang, Q.; Wu, Q. Optimisation of ultrasound assisted extraction of phenolic compounds from Sparganii rhizoma with response surface methodology. Ultrason. Sonochem. 2013, 20, 846-854. [CrossRef]

28. Kazemi, M.; Khodaiyan, F.; Hosseini, S.S. Eggplant peel as a high potential source of high methylated pectin: Ultrasonic extraction optimization and characterization. LWT Food Sci. Technol. 2019, 105, 182-189. [CrossRef]

29. Talhaoui, N.; Gómez-Caravaca, A.M.; León, L.; De la Rosa, R.; Segura-Carretero, A.; Fernández-Gutiérrez, A. Determination of phenolic compounds of 'Sikitita' olive leaves by HPLC-DAD-TOF-MS. Comparison with its parents 'Arbequina'and 'Picual'olive leaves. LWT Food Sci. Technol. 2014, 58, 28-34. [CrossRef]

30. Talhaoui, N.; Taamalli, A.; Gómez-Caravaca, A.M.; Fernández-Gutiérrez, A.; Segura-Carretero, A. Phenolic compounds in olive leaves: Analytical determination, biotic and abiotic influence, and health benefits. Food Res. Int. 2015, 77, 92-108. [CrossRef]

31. Ranalli, A.; Contento, S.; Lucera, L.; Di Febo, M.; Marchegiani, D.; Di Fonzo, V. Factors affecting the contents of iridoid oleuropein in olive leaves (Olea europaea L.). J. Agric. Food Chem. 2006, 54, 434-440. [CrossRef] [PubMed]

32. Abaza, L.; Taamalli, A.; Arráez-Román, D.; Segura-Carretero, A.; Fernández-Gutierrérez, A.; Zarrouk, M.; Youssef, N.B. Changes in phenolic composition in olive tree parts according to development stage. Food Res. Int. 2017, 100, 454-461. [CrossRef] [PubMed]

33. Xiao, Q.; Zhang, L.; Zhou, L.; Wu, K. Study on olive development in China. Am.-Eurasian J. Agric. Environ. Sci. 2009, 5, 414-419.

34. Malik, N.S.; Bradford, J.M. Changes in oleuropein levels during differentiation and development of floral buds in 'Arbequina'olives. Sci. Hortic. 2006, 110, 274-278. [CrossRef]

35. Vinha, A.F.; Ferreres, F.; Silva, B.M.; Valentao, P.; Gonçalves, A.; Pereira, J.A.; Oliveira, M.B.; Seabra, R.M.; Andrade, P.B. Phenolic profiles of Portuguese olive fruits (Olea europaea L.): Influences of cultivar and geographical origin. Food Chem. 2005, 89, 561-568. [CrossRef]

36. Arabshahi-Delouee, S.; Urooj, A. Antioxidant properties of various solvent extracts of mulberry (Morus indica L.) leaves. Food Chem. 2007, 102, 1233-1240. [CrossRef]

37. Malheiro, R.; Sousa, A.; Casal, S.; Bento, A.; Pereira, J.A. Cultivar effect on the phenolic composition and antioxidant potential of stoned table olives. Food Chem. Toxicol. 2011, 49, 450-457. [CrossRef] 
38. Şahin, S.; Bilgin, M. Olive tree (Olea europaea L.) leaf as a waste by-product of table olive and olive oil industry: A review. J. Sci. Food Agric. 2018, 98, 1271-1279. [CrossRef]

39. Visioli, F.; Galli, C. Olive oil phenols and their potential effects on human health. J. Agric. Food Chem. 1998, 46, 4292-4296. [CrossRef]

40. Quirantes-Piné, R.; Zurek, G.; Barrajón-Catalán, E.; Bäßmann, C.; Micol, V.; Segura-Carretero, A.; Fernández-Gutiérrez, A. A metabolite-profiling approach to assess the uptake and metabolism of phenolic compounds from olive leaves in SKBR3 cells by HPLC-ESI-QTOF-MS. J. Pharm. Biomed. Anal. 2013, 72, 121-126. [CrossRef] 